\section{CONCLUSION}

APSA, as an association, is very fortunate to have many, many members who devote time and resources in support of our extensive programming including the annual meeting and its publications. This past year has been extraordinarily challenging for everyone, and it is impossible to overstate how grateful we are for the tremendous service work of our members under these trying circumstances. Our volunteer leadership and our staff have also provided terrific support to APSA's programming and APSA members and we very much appreciate their work. I look forward to working with our members and the APSA staff in 2021, as we address the continued challenges facing the discipline and higher education as a whole, and as we continue to develop programs to support the research and pedagogical interests of our members and their professional development and engagement in the public sphere.
NOTES

1. https://connect.apsanet.org/respect/

2. https://www.apsanet.org/RESOURCES/APSA-Resources-for-Address-

ing-Systemic-Racism-Social-Justice

3. https://educate.apsanet.org/

4. https://preprints.apsanet.org/engage/apsa/public-dashboard

5. https://apsanet.org/democracy2020

6. https://www.apsanet.org/PROGRAMS/Doctoral-Dissertation-Research-Improvement-Grants/Application-Materials-and-Format

\title{
APSA Announces the Formation of the Careers Diversity Committee
}

\author{
DAVID LAZER | NORTHEASTERN UNIVERSITY
}

T

he Careers Diversity Committee will advise APSA on support for political scientists who seek careers in government, industry, nonprofits, and academia by planning events and programs designed to advance career diversity and recruit APSA members from across these careers.

The primary objective of this committee is to identify ways that APSA can help build career opportunities for doctoral students and faculty outside of the academy. Building these opportunities serves multiple purposes. First, providing more opportunities to political scientists will allow them to build lives-in or outside of the academy-best aligned with their life objectives. Second, the ideas and methods of the discipline have substantial and underutilized relevance to the world. Governance, justice, pow-

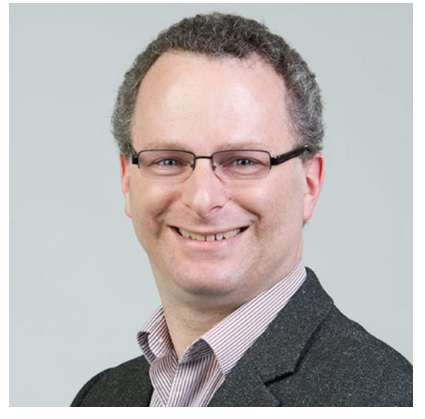

er, and ethics are issues that are pervasive across all institutions. Creating capacity within institutions to constructively engage those issues is an important way that the discipline can create value. Methods, from ethnography, to survey research, to emerging computational methods to analyze complex data, have potential to produce valuable insights for government, nonprofits, and for profits. Third, the committee addresses the limited supply of university positions: The field is currently training far more doctoral students than it can accommodate within the academy.

An additional, and complementary, objective of the committee is to evaluate how to make APSA more inclusive of political scientists who have built careers outside of the academy, but who are still using and building on disciplinary concepts and methods. APSA should serve the discipline at large, and not just within the academy. By building a more inclusive discipline, in terms of career paths, APSA will build opportunities for our members and bridges of intellectual exchange between the academy and government, nonprofits, and for profits that will facilitate knowledge creation and constructive application of that knowledge.

Members of the committee include Ben Campbell (CoverMyMeds), Sarah Binder (George Washington University and Brookings Institution), Andrew Holbrook (Wells Fargo), John Haskell (John W. Kluge Center, Library of Congress), Natalie Jackson (Public Religion Research Institute), Juhem Navarro-Rivera (Socioanalitica Research), Lee Walker (University of North Texas), and David Lazer, chair, (Northeastern University and Institute for Quantitative Social Science, Harvard University). .

David Lazer is a University Distinguished Professor of Political Science and Computer Sciences at Northeastern University and codirector of the NULab for Texts, Maps, and Networks. 